\title{
The snowmelt as a critical period for the quality of surface water in the agricultural catchment
}

\author{
Matgorzata Krasowska ${ }^{1, *}$ \\ ${ }^{1}$ Bialystok University of Technology, Department of Environmental Protection and Management, 45E \\ Wiejska Street, 15-351, Poland
}

\begin{abstract}
The research on the quality of the water of a small watercourse was conducted in the agricultural catchment in north-eastern Poland. The water quality was analyzed in the hydrological year and in the period of increased discharge, which in these hydro-meteorological conditions occurs in the snowmelt period. Nutrients get from agricultural land to surface water during the snowmelt or precipitation period. Therefore, the chemical composition of the water of the studied watercourse was subject to intense seasonal fluctuations. The concentration of nitrates, phosphates and ammonium ions increased with discharge. The snowmelt lasted for several days. However, as research has shown, this is a critical period for the quality of surface water in the agricultural landscape. During this period, the water of a small watercourse transported about $36 \%$ of annual nitrate load, over $45 \%$ of phosphate load and as much as $66 \%$ of ammonium ions.
\end{abstract}

\section{Introduction}

The soils of farmland are the main source of scattering of dissolved substances into surface water [1-9]. Chemical compounds in the form of mineral and organic fertilizers, which are introduced into soils, as well as activated in soil and not used by plants, are leached by rainwater and snowmelt, and then they get to groundwater and a watercourse with surface or underground runoff $[10,11]$. In processes of leaching chemical constituents from the catchment to the watercourse, atmospheric factors have the greatest influence. They determine the movement of water in the soil as well as the rate of mineralization of organic substances [12].

In Poland, an important characteristic that describes the distribution of water outflow and dissolved substances in catchment is their seasonality. Its variability depends on the physical and geographical conditions, in particular on the climate, morphology, geological structure, land cover and the method and intensity of the catchment management [13, 14]. It is assumed that the largest transport of dissolved substances occurs during freshets caused by snow melting or rainfall. Particularly noteworthy are snowmelt floods, when there is an intensive elution of dissolved substances accumulated in the catchment [15-19]. During floods of thaw, surface and subsurface runoff is formed and there is an increased migration of dissolved substances, including nutrients, into surface water. It seems that leaching of substances dissolved from the agricultural catchment during the snowmelt may be a period of intense

* Corresponding author: m.krasowska@pb.edu.pl 
denudation, especially in the hydro-meteorological conditions of north-eastern Poland. Therefore, the purpose of the present study was to analyze the chemical composition of the water of the watercourse in the agricultural catchment, with particular emphasis on the flood period.

\section{The study area}

The research was conducted in a part of the agricultural catchment, a small watercourse, which is located in north-eastern Poland, in the Podlasie voivodship, in the municipality of Choroszcz. The analyzed stream is a left tributary of Horodnianka, which flows into the Supraśl River (Fig. 1). The studied catchment has an area of 187 ha and a circumference of about $6 \mathrm{~km}$.

The watercourse is regulated and there is no natural source because it starts from the drain. It measures about $1550 \mathrm{~m}$ from the outflow to the research section and there are three surface inflows in this section.

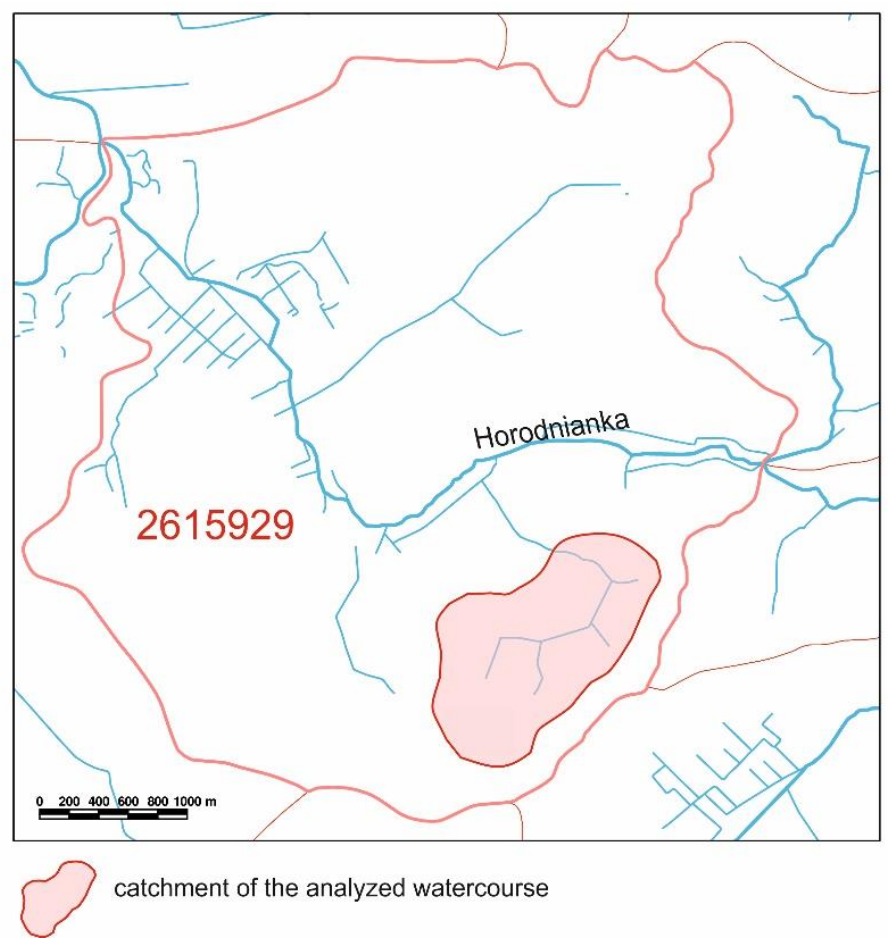

Fig. 1. The studied part of the catchment of the watercourse against the background of the Horodnianka catchment from the inflow from Łyski to the estuary.

In terms of climate, the area of research belongs to the XII Mazursko-Podlaski Region, which is characterized by the highest frequency of the appearance of the coldest weathers [20]. Frost extends from October to May. The growing season begins in mid-April and ends in the third decade of October. The rainfall dominate in the studied area, while snowfall accounts for an average of about $22 \%$ of the annual sum. The snow cover stays from the beginning of November to the end of April and is most often unstable, which is due to the effects of the thaw [21].

The dominating way of land use is relatively low-intensity agriculture. The main use of the catchment is arable land, which covers about $75 \%$ of the area. Permanent grasslands are predominantly located in the watercourse valley and occupy $16 \%$ of the catchment. Forests 
are small-surface and cover only $3.5 \%$ of the area, and built-up areas and wasteland occupy $5.5 \%$ of the catchment area. The agricultural land is drained, about $40 \%$ of their area is drained by a tile network.

\section{Methods}

The hydrochemical studies were conducted throughout the hydrological year in the agricultural catchment. Intensive research was carried out during the snowmelt floods. They consisted of measurements of atmospheric and hydrological conditions as well as analysis of selected physicochemical properties of water from the watercourse. The water level in the watercourse, on the closing cross-section (hydrometric), was measured at regular intervals every 30 minutes using the CTD Diver (Schlumberger Ltd.), then, they were converted into flow values.

The samples of water from the watercourse were collected for laboratory tests once a week. During flood periods caused by melting snow cover, samples were taken every two hours using an automatic GLS 6712 ISCO (Teledyne Isco) device.

Selected physicochemical properties, such as: electrolytic conductivity (EC) and ion concentration: $\mathrm{H}^{+}, \mathrm{NO}_{3}{ }^{-}, \mathrm{NH}_{4}^{+}, \mathrm{PO}_{4}{ }^{3-}, \mathrm{SO}_{4}{ }^{2-}, \mathrm{Cl}^{-}, \mathrm{Mg}^{2+}, \mathrm{Ca}^{2+}$ were determined in water samples

Loads of ions in the river's outflow during the entire hydrological year and during the freshet were calculated using the formula (1) [22]:

$$
l_{k}(j)=\sum_{i=1}^{k} \frac{\Delta t_{i}\left[c_{i}(j) Q_{i}+c_{i+1}(j) Q_{i+1}\right]}{2}[\mathrm{~kg}]
$$

where:

$1_{\mathrm{k}}(\mathrm{j}) \quad$ - the cumulative load of component $j$ in the time interval $k$,

$\Delta \mathrm{t}_{\mathrm{i}} \quad$ - the time interval $i$ between measurements,

$\mathrm{c}_{\mathrm{i}}(\mathrm{j})$ - the instantaneous concentration of the component $j$,

$\mathrm{Q}_{\mathrm{i}} \quad$ - instantaneous flow.

\section{Results}

The increased concentration of nitrates and phosphates was recorded in March, during the snowmelt period. The another increase was in autumn during high water levels due to rainfall. The lowest concentrations of these ions were found in the summer months at low flows. the concentration of ammonium ions changed dynamically throughout the year. The maximum concentration was found in February before the flood wave. The concentration of this ion decreased during its descent, and another increase was before intense rainfall, in the summer months. The highest concentration of sulphates was recorded in December, during low water levels. The content of this ion decreased significantly during the culmination of the flow. The calcium content $\left(\mathrm{Ca}^{2+}\right)$ was characterized by the highest fluctuations in the initial flooding phase. In February 2010, the $\mathrm{Ca}^{2+}$ concentration reached about $205 \mathrm{mg} \cdot \mathrm{dm}^{-3}$, after which the concentration of this ion decreased, which was clearly influenced by the inflow of meltwater and rainwater. The magnesium and chloride content was characterized by high dynamics in the water of the watercourse. The maximum concentration of these ions was noted after the flood wave in March, which was related to the leaching of the substance dissolved from the catchment (Tab. 1).

The content of most ions changed in the water of the watercourse during increased flows. The lower content of dissolved substances was recorded in the initial phase of the snowmelt, while the concentration of dissolved material increased just after the culmination and in the recessionary phase of the flood (Fig. 2). 
Table 1. Average monthly values of selected physicochemical parameters.

\begin{tabular}{|l|c|c|c|c|c|c|c|c|c|c|}
\hline \multirow{2}{*}{ Month } & $\mathrm{EC}$ & $\mathrm{H}^{+}$ & $\mathrm{NO}_{3}^{-}$ & $\mathrm{NH}_{4}^{+}$ & $\mathrm{PO}_{4}^{3-}$ & $\mathrm{SO}_{4}{ }^{2-}$ & $\mathrm{Si}_{2} \mathrm{O}_{3}{ }^{2-}$ & $\mathrm{Cl}^{-}$ & $\mathrm{Mg}^{2+}$ \\
\cline { 2 - 12 } & {$\left[\mu \mathrm{S} \cdot \mathrm{cm}^{-1}\right]$} & \multicolumn{9}{|c|}{$\left[\mathrm{mg}^{-1} \mathrm{dm}^{-3}\right]$} \\
\hline January & 589 & 7.9 & 21.3 & 0.3 & 0.1 & 41.8 & 0.4 & 14.5 & 21.1 \\
\hline February & 557 & 7.8 & 20.0 & 0.4 & 0.0 & 30.6 & 0.9 & 13.7 & 18.4 \\
\hline March & 605 & 7.8 & 35.4 & 0.3 & 0.1 & 40.6 & 1.0 & 13.7 & 30.1 \\
\hline April & 605 & 7.8 & 27.5 & 0.1 & 0.0 & 52.3 & 1.0 & 16.6 & 17.2 \\
\hline May & 596 & 8.2 & 15.5 & 0.3 & 0.1 & 38.3 & 0.9 & 11.7 & 34.3 \\
\hline June & 654 & 7.6 & 11.0 & 0.3 & 0.0 & 51.0 & 1.7 & 16.5 & 29.3 \\
\hline July & 548 & 7.5 & 11.9 & 0.4 & 0.1 & 42.7 & 1.1 & 14.3 & 39.3 \\
\hline August & 586 & 7.9 & 5.5 & 0.1 & 0.1 & 44.5 & 1.7 & 13.3 & 37.3 \\
\hline September & 626 & 7.2 & 46.7 & 0.2 & 0.3 & 51.4 & 0.6 & 12.6 & 35.6 \\
\hline October & 679 & 8.2 & 21.0 & 0.2 & 0.0 & 60.4 & 1.1 & 15.6 & 40.7 \\
\hline November & 675 & 8.5 & 21.5 & 0.1 & 0.0 & 61.7 & 1.0 & 13.7 & 33.1 \\
\hline December & 688 & 9.6 & 24.5 & 0.4 & 0.1 & 124.0 & 1.4 & 14.8 & 31.6 \\
\hline
\end{tabular}

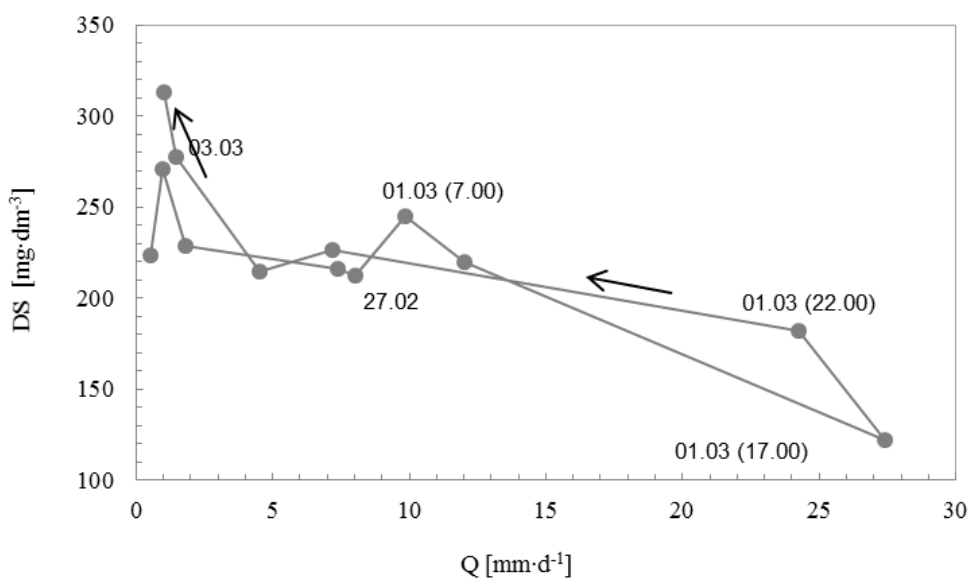

Fig. 2. The relationship between discharge (Q) and the concentration of the dissolved substance (DS) during the snowmelt.

The changes in the concentration of most ions in the water of the watercourse were correlated with the discharge. The increasing the discharge caused a decrease in the electrolytic conductivity $(\mathrm{EC})$ of water $(\mathrm{R}=-0.827, \mathrm{p}<0.01)$ and the content of such ions as: $\mathrm{Ca}^{2+}(\mathrm{R}=-0.610), \mathrm{Mg}^{2+}(\mathrm{R}=-0.713), \mathrm{Cl}(\mathrm{R}=-0.610)$ and $\mathrm{SO}_{4}{ }^{2-}(\mathrm{R}=-0.441)$. These ions were characterized by the highest concentration during low water levels. During the snowmelt, the content of ions decreased as a result of dilution by weakly mineralized rainwater and meltwater reaching the watercourse in the form of surface runoff and subsurface. The sulphate content was constantly fluctuating, the lowest concentration reached at the moments of the highest discharge in the watercourse (Fig. 3).

The dynamics of $\mathrm{NO}_{3}{ }^{-}$and $\mathrm{PO}_{4}{ }^{3-}$ ion migration into surface water shows a graph of the hysteresis effect occurring between the concentration of these ions and the discharge (Fig. 4). The first increase in the concentration of $\mathrm{NO}_{3}{ }^{-}$ions, to the value of about $40 \mathrm{mg} \cdot \mathrm{dm}^{-3}$, was noted in the initial phase of flooding, at the time of intensive melting snow cover. The concentration of nitrates decreased as the flow of water increased during the culmination of the flood wave. This indicates their dilution by the water reaching the trough. The concentration of nitrates increased again after the culmination of the snowmelt. However, when the watercourse was fed by groundwater (after March 3), the $\mathrm{NO}_{3}{ }^{-}$content decreased, 
but it was still higher than before the freshet. The concentration of $\mathrm{PO}_{4}{ }^{3-}$ was positively correlated with the discharge $(\mathrm{R}=0.813, \mathrm{p}<0.01)$. Initially, the phosphate content increased with increasing flow, however, the maximum of over $0.5 \mathrm{mg} \cdot \mathrm{dm}^{-3}$ was in the recession phase of the snowmelt.

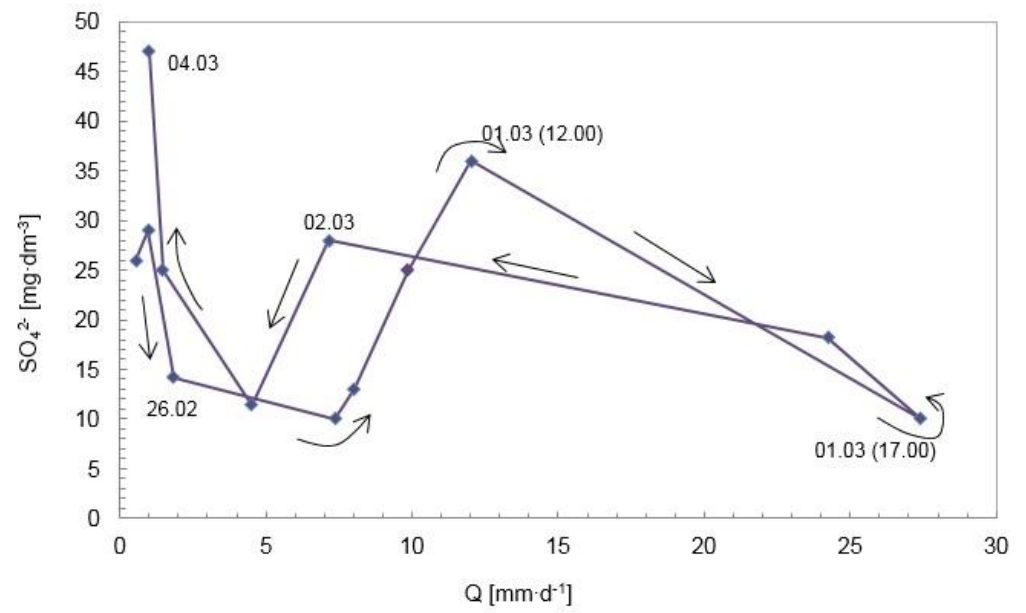

Fig. 3. The relationship between discharge (Q) and the concentration of $\mathrm{SO}_{4}^{2-}$ during the snowmelt.

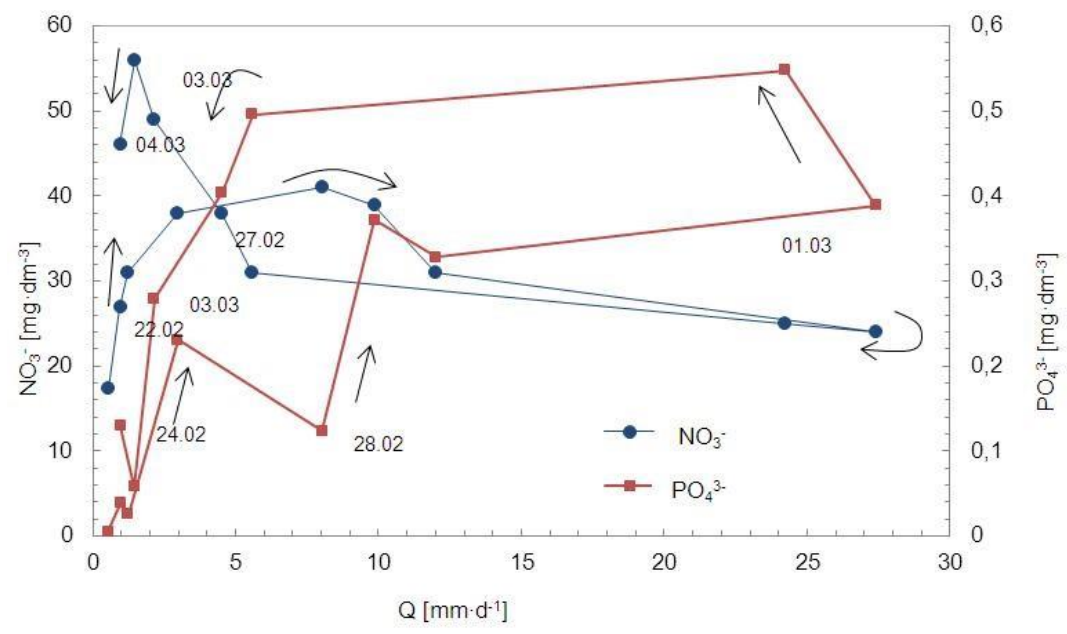

Fig. 4. The relationship between discharge (Q) and the concentrations of $\mathrm{NO}_{3}{ }^{-}$and $\mathrm{PO}_{4}{ }^{3-}$ during the snowmelt.

Within a few days during the snowmelt, the flow of water in the watercourse increased. In addition, during this time the amount of loads of the examined ions represented from over a dozen to over 65 percent of annual loads (Tab. 2). 
Table 2 The loads of ions transported by the stream of water throughout the hydrological year and during the snowmelt period.

\begin{tabular}{|c|c|c|c|c|c|c|c|c|c|}
\cline { 2 - 9 } \multicolumn{1}{c|}{} & $\mathrm{Q}$ & $\mathrm{NO}_{3}{ }^{-}$ & $\mathrm{NH}_{4}^{+}$ & $\mathrm{PO}_{4}{ }^{3-}$ & $\mathrm{SO}_{4}^{2-}$ & $\mathrm{Si}_{2} \mathrm{O}_{3}^{2-}$ & $\mathrm{Cl}^{-}$ & $\mathrm{Mg}^{2+}$ \\
\cline { 2 - 10 } & {$\left[\mathrm{m}^{3}\right]$} & \multicolumn{7}{c|}{$[\mathrm{kg}]$} \\
\hline $\begin{array}{c}\text { hydrological } \\
\text { year }\end{array}$ & 123384 & 3287.4 & 43.5 & 15.9 & 5240.4 & 119.9 & 1652.4 & 3031.41 \\
\hline $\begin{array}{c}\text { period of } \\
\text { snowmelt }\end{array}$ & 78634 & 1168.2 & 19.7 & 10.6 & 693.9 & 42.2 & 408.5 & 584.4 \\
\hline$\%$ & 63.7 & 35.5 & 45.3 & 66.7 & 13.2 & 35.2 & 24.7 & 19.3 \\
\hline
\end{tabular}

\section{Summary}

The chemical composition of river water changed seasonally. The concentration of nitrates, phosphates and ammonium ions increased with higher discharge. The highest concentration of nutrients was observed during snowmelt in the early spring period, while the lowest concentration was recorded during low water levels in the non-precipitation period.

During the snowmelt, the stream water transported about $36 \%$ of the annual load of nitrates, over $66 \%$ of phosphates and over 45 of ammonium ions. In the case of nitrates, the admissible value was exceeded, according to the regulation of the Minister of the Environment of 22/10/2014 [23].

It can be presumed that intensive seasonal nutrient leaching may contribute to the bed chemical condition of surface water in agricultural areas [2]. As part of the diagnostic monitoring in 2010-2015, the chemical status of river surface water in $28 \%$ was rated below the good one [24].

The socio-economic changes occurring in Poland also entail transformations in the agricultural economy and perception of the role of rural areas. More and more attention is paid to the need to take into account non-productive functions, including ecological ones. Therefore, systemic actions are necessary that lead to the protection and improvement of the quality of ecosystems, including the protection of surface and underground water resources [25].

The acknowledgments: research was funded by Ministry of Science and Higher Education as a part of the project S/WBiIŚ/02/15.

\section{References}

1. K.L. Campbell, D.R. Edwards, CRC Press LLC, Boca Raton, 91-109 (2001)

2. J.L. Campbell, M.J. Mitchell, P.M. Groffman, L.M. Christenson J.P. Hardy, Front Ecol. Environ. 3, 6 (2005)

3. Z. Zabłocki, P. Pieńkowski, M. Kupiec, Agricultura 87 (2001)

4. K. Kyllmar, C. Carlsson, A. Gustawson, B. Ulen, H. Johnsson. Agriculture, Ecosystems and Environment 115 (2006)

5. M. Sojka, S. Murat-Błażejewska, J. Kanclerz, Zesz. Probl. Postępów Nauk Rol. 526 (2008)

6. A. Czajkowska, Górnictwo i Geologia 5, 4 (2010)

7. Z. Czerebiej D. Szatten, Ż. Marciniak, Journal of Health Sciences 3, 14 (2013)

8. M. Skorbiłowicz, J. of Ecol. Eng. 14 (2013) 
9. Z. Miatkowski, K. Smarzyńska, Woda Środ.-Obsz. Wiej. 14, 3 (2014)

10. A. Sapek, Zeszyty Edukacyjne 7, (2002)

11. V.G. Rumynin, Springer (2015)

12. M. Ostrowska, Problemy Ekologii 14, 3 (2010)

13. M. Skorbiłowicz, P. Ofman, J. of Ecol. Eng. 15, 1 (2014)

14. P. Jokiel, P. Tomalski, Przegląd Geograficzny 87, 1 (2015)

15. M. Żelazny, IGiGP UJ (2005)

16. M. Stolarska, Acta Geographica Lodziensia, 94 (2008)

17. M. Żelazny, A. Wolanin, E. Płaczkowska, Fundacja Rozwoju Uniwersytetu Gdańskiego, 461-467 (2009)

18. Y. Kawabata, M. Kawai, M. Yamada, S. Onwona-Agyeman, V. Aparin, B. Jollibekov, T. Kurita, M. Nagai, Y. Katayama Y., Journal of Arid Land Studies, 22, 1 (2012)

19. P. Moniewski, Monografia KGW-PAN, XX, 2 (2014)

20. A. Woś, Wyd. Nauk. PWN (1999)

21. A. Górniak, Wyd. IMGW Białystok (2000)

22. W.A. House, D.V. Leach, P.D. Armitage, Water Res. 35, 11 (2001)

23. Rozporządzenie Ministra Środowiska z dnia 22 października 2014 r. (Dz. U. 2014 poz. 1482).

24. GIOŚ, Warszawa (2017)

25. J. Siuta, Inżynieria Środowiska 34 (2013) 